" . . - if I examine the nature of this proposition that 'the properties of matter might have been' other than they are. Does it express an experimentally-ascertained truth? If so, I invite Prof. Tait to describe the experiments !"

P. G. TAIT

\section{Animal Locomotion}

My former letter on this subject was merely to show that, mechanically, Dr. Pettigrew's view of the forward motion or inclination of a bird's wing during the down stroke was less absurd than had been supposed, and even seemed necessary to flight. I did not profess to have made accurate observation or experiment on the point. I accept, therefore, the observation of the Duke of Argyll as to the vertical motion of the heron's wing; but as he expressly refers to its great concavity, that would give a vertical down stroke the effect of a somewhat forward stroke of a flatter wing. The proper inference would therefore seem to be, that in birds with less concave wings the stroke is slightly directed forwards. As to the last two paragraphs of his Grace's letter, he will see, if he refers again to mine, that he has quoted words I never used. I impute to Dr. Pettigrew the "merit of showing "that the "slight upruard angle of the mean position of the wing plane is essential to secure horizontal forward motion as a general resultant," \&c., and this is exactly what the Duke denies.

Mr. James Ward's elaborate analysis of the down stroke of a bird's wing simply shows (if correct) that in the position he ascribes to it (moving downward and backward) it would send the bird horizontally forward. Of course it would. But then what becomes of the bird during the up stroke in an opposite direction? The bird is then falling, and by the downward reaction of all the solid surface of the anterior margin of the wing, and of all the feathers, however obliquely turned, it is driven farther downwards; and as this takes place between every two down strokes, and approximately during an equal space of time, how is a horizontal average motion to be produced unless the down stroke alone produces, not a horizontal, but a highly-inclined upward motion? Mr. Ward's whole argument appears to me to ignore the great downward reaction, added to gravitation, during every up stroke, which requires that the down stroke should not merely support the bird, but raise it up vertically just as much as during the up stroke it has fallen vertically. The matter, however, is not to be settled by discussing theoretically, but by observation and experiment. I simply maintain that the results of Dr. Pettigrew's observations and experiments are not, as supposed, inconsistent with mechanical principles; and nothing in your correspondent's letter induces me to alter that opinion.

\section{AlFRED R. WALLACE}

\section{The Newfoundland Cuttie-Fish (Mesaloteuthis harveyi S. Kent)}

M $\times$ right being questioned, through an anonymous paragraph in the Globe of the IIth inst., to institute a new generic title for the gigantic Cephalopod encountered off Newfoundland, and of which I communicated an account to the Zooloyical Society's meeting of March 3, I would briefly reply to my criticiser in these columns.

In the first place, it is a somewhat anomalous proceeding to raise objections on such a question before details of the grounds upon which it has been deemed advisable to establish such a title have appeared, as in the ordinary course of events they will, in the "Proceedings" of the Society. In these it will be found that ample reasons are given for the course that has been taken, as also due notice of both Prof. Steenstrup's and Prof. Verrill's researches in a similar direction. Had my assailant placed himself more thoroughly au courant with the details of the case, he would possibly have held back his emphatic assertion that Prof. Verri: 1 had "actually identified the species from Newfoundland with those described by Steenstrup as belonging to his genus Architeuthis." This identification in Prof. Verrill's own language is entirely problematical, and must unfortunately remain so, since a beak only, an organ of no value in generic discrimination, has been preserved of the typical species $A$. dux. Respecting the second form, $A$. monachus, we have still less knowledue, the title being provisionally instituted by Prof. Steenstrup for the recepiion of two gigantic Cephalopods cast on the shores of Jutland in the years 1639 and 1790 , and of which popular record alone remains.

In reference to the "imperfect evidence" asserted by my critic to be at my command, I may state that I received accounts of the examples, upon which I have proposed to base my new title of Megaloteuthis, direct from America as long ago as in the beginning of December last, supplemented by numerous fuller details since.

W. Saville-Kent

\section{Lord Lindsay's Expedition}

THE expedition of Lord Lindsay for observation of the Transit of Venus at Mauritius (why will people still call it the Mauritius?) will afford a good opportunity for re-measuring the base line of Abbé de la Caille, made in 1753 , and which, to the best of my belief, has never been since verified.

The small conical cairns which mark its extremities should still be found in situ. I saw one only of them in November 1864, when I had not time to search for the other. The base measured was $I, 828$ toises in length, and, I imagine, on the meridian. It was on a level plain at the south-west extremity of the island, close under the western slopes of the precipitous and noble "Morne du Brabant," which rises nearly I, 700 feet above the sea-level. By road the distance of this spot from Port Louis must be at least 30 miles, but it is much more easily reached direct by boat; or, as December is a bad time of year for boating outside the reefs, the best route would be from Black River by water inside the isle Bénitier. It is a glorious district, all that part of the island, and contains the finest scenery, including the Chamaral Falls.

Buncrana, near Londonderry, March 14

S. P. Oliver

\section{QUETELET}

$\mathrm{O}^{\mathrm{N}}$ February i7 last Jacques-Ädolphe-Lambert Quetelet died at Brussels, in the seventy-eighth year of his age, having been born on February 22, I796, at Ghent. At the early age of 18 he was appointed Professor of Mathematics in the College of his native town. In July, 1819 , the degree of Doctor of Science was conferred on him by the University of Ghent, then recently founded by King William. His dissertation on this occasion was so well received that he was shorly thereafter appointed to the Chair of Mathematics at the Royal Athenæum of Brussels; and in February following was elected a member of the Academy of Sciences and Belles-Lettres.

At this time he applied himself with ardour to the cultivation of literature and pure mathematics, thus laying a sure foundation for the world-wide fame he afterwards achieved as an exact investigator in many departments of physics, as an original thinker in applying methods of scientific treatment to the discussion of problems pre, viously considered as belonging exclusively to moralists and divines, and as a clear and eloquent expounder of the truths he had demonstrated. The many-sidedness and fertility of his mind may be seen from his scientific memoirs enumerated in the Royal Society's Catalogue of Scientific papers, amounting at the close of 1863 to 220 . $\mathrm{He}$ continued to write almost to the last, notwithstanding. the mental malady, consisting in loss of memory, with which he was afflicted many years before his death, and it is noteworthy that even to the last his handwriting retained much of the rare grace and elegance for which it had been so remarkable.

'The earliest of Quetelet's published memoirs, begun in I 820 , were on geometrical subjects. The non-appreciation of these by the public determined him to devote himself to physical science and astronomy. On these subjects he lectured publicly with great success.

In 1823 he was sent on a mission to Paris with the view. of preparing a report on the observatory of that city for the guidance of the Belgian Government in founding a similar observatory at Brussels. After some delay, the observatory was established, with Quetelet as director, and in 1833 began the long series of observations on astronomy, meteorology, and other physical inquiries, for which this observatory is so well known. The most important of his astronomical observations was the prepara- 
tion of a catalogue, begun in 1857 , of stars which seem to have appreciable motion. He also began, so early as 1836 , systematically to observe and record the occurrence of meteors and shooting-stars. These observations came to be of great value thirty years later, when the true nature of these bodies was satisfactorily established.

The meteorological observations at this observatory have been particularly full and valuable, embracing hourly and bi-hourly observations, published annually in extenso, of atmospheric pressure, temperature, humidity, rain, cloud, \&c. These have been exhaustively discussed by Quetelet in "La météorologie de la Belgique comparée à celle du globe," published in 1867 . In this admirable treatise we have what must still be regarded as the fullest and best account of the meteorology of any single locality on the globe-the yearly, monthly, daily, and hourly march of the various meteorological elements being given. In the same volume are given résumés of the observations made at the other stations which began to be established at Alost, Ghent, Liége, \&c., in 1835.

He was elected perpetual secretary of the Academy of Sciences and Belles-Lettres in November 1834, and was chiefly instrumental in adding a section on the Fine Arts in 1845 . It is scarcely necessary to refer to the scientific contributions he made to the Fine Arts, by his extensive and minute investigations regarding the proportions of the human body, the results of which are given in his "Anthropométrie." In matters relating to the higher education, to the census, and other national questions, the Belgian Government wisely availed itself repeatedly of his wide knowledge and great experience.

His first paper on the subject of statistics was published in 1826 ; in 1835 appeared his "Physique sociale," and ten years later his "Lettres sur la théorie des probabilités appliquées aux sciences morales et politiques." In 1841 a Central Commission of Statistics was established by royal decree, of which Quetelet was made president, and of which he continued to be president to his death. $\mathrm{He}$ originated the idea of convening an International Congress of Statistics. The first was held in Brussels in I 853 , and others have since been held at Paris, London, Berlin, Florence, the Hague, and St Petersburg. It is in the field of statistics that Quetelet appears as a great discoverer, and his success in this department must be attributed to the clearness with which he saw that statistics occupy the ground in the development of the social and political sciences which observational data do in the development of such sciences as astronomy and meteorology, to the patient industry with which through long years he gathered together his facts, and to the mathematical skill he brought to bear on the discussion of the results. He was truly, as expressed by the Academy of Berlin in their congratulatory letter on the ocrasion of the centenary of the Belgian Academy, "the founder of a new science which proceeds from the firm basis of observation and calculation to discover and unfold those immutable laws which govern the phenomena, apparently the most accidental, of the life of man, down even to his most trivial actions."

\section{SIIENTIFIC RESULTS OF THE "POLARIS" ARCTIC EXPEDITION}

$\mathrm{WE}$ have received advanced sheets of the Report of the Secretary of the United States Navy, of the examination of those of the crew of the Polaris who were in the ship when she broke loose from the floe to which she was anchored, on October 15, 1872, leaving the nineteen persons on the sheet of ice which was their floating home, until picked up about six months after off the coast of Labrador (NATURE, vol. viii., p. 2I7). This report confirms the opinion we have already expressed that no Arctic expedition can be adequately conducted unless carried out under naval discipline. It was only on account of the good intentions and good nature of the crew, especially after their noble and enthusiastic captain's death, that things went on as smoothly as they did. Captain Buddington seems to have had no heart in the object of the expedition, and we cannot help thinking that had he not been with it much more would have been gained. It was in deference to his opinion that Captain Hall refrained from trying to push beyond his furthest point $\left(82^{\circ} 16^{\prime} N\right.$.) with the ship; all the other officers, though they do not seem to have been very well assorted, being of opinion that an attempt should be made to get further north, or at least not to lose ground by wintering further south.

We have already (vol. viii., p. 435) given details as to the rescue of those who were left in the Polaris, and of their being landed in Scotland by the Arctic and Eric whalers. The present report affords some idea of the scientific results of the expedition, a detailed account of which will no doubt by and by be published, although we regret to see that many of the records of the scientific results were lost in the confusion incident to the parting of the ship from the floe. Still much that is valuable has been brought home, from which many additions to a scientific knowladge of that part of the Arctic region will be obtained. Notwithstanding the want of perfect harmony among the officers, the scientific work of the expedition seems to have been diligently carried on, and the evidence of Dr. Bessels especially contains a great deal of value to Science. Geographers will be able to correct and extend their maps of the regions visited, and we hope that very soon the complete material for enabling them to do so will be in their hands. Constant and careful tidal observations were carried on, with the very valuable result of ascertaining that the tide of Thank-God Harbour, $81^{\circ} 38^{\prime} \mathrm{N}$, is not produced by the Atlantic but by the Pacific tidal wave. "It was found," Dr. Bessels says, "that the co-tidal hour is about $6^{\text {th }} 20^{\text {mi }}$. Rensselaer Harbour, being the northermost station, has its co-tidal hour at $18^{\text {h }} 04^{\mathrm{m}}$, consequently the tide comes from the north, the rise and fall at spring. tides amounting to about $5 \mathrm{ft}$. ; at neap tides $2 \frac{3}{50}$. Most likely the two tidal waves meet somewhere in Smith Sound, near Cape Frazier. Kane and Hayes have both found a ridge of hummocks near Cape Frazier, and in drifting down we experienced that during some time, being abreast of Cape Frazier ; we hardly made any headway, but we drifted both north and south."

The results of the expedition may be summed up briefly as follows:-(r) the Polaris reached $82^{\circ} 16^{\prime}$ N., a higher latitude than has been attained by any other ship; (2) the navigability of Kennedy Channel has been proved beyond a doubt; (3) upwards of 700 miles of coast-line have been discovered and surveyed; (4) the insularity of Greenland has been proven; and (5) numerous observations have been made relating to astronomy, magnetism, force of gravity, ocean physics, meteorology, zoology, ethnology, botany, and geology, the records of which were kept in accordance with the instructions supplied by the National Academy, and some of the results of which we propose briefly to enumerate.

AsTronomy.--Great care was taken in determining a reliable meridian at Thank-God Harbour. Soon after entering winter-quarters an observatory was erected on the shore, thirty-four feet above mean sea-level, and the transit instrument stationed there. The longitude of this station was determined by the observation of 300 lunar distances; a number of moon culminations; a great number of star transits ; a number of star occultations ; a great number of altitudes of the sun on or near the prime vertical. Its latitude, by the observation of a great number of circummeridian altitudes of the sun, and a number of altitudes of stars. All of these observations were lost, but a number of the results have been preserved which are sufficient to establish the position of his station. 